5. A paper-chromatographic technique is given for the separation and detection of the reduced and oxidized forms of ergothioneine, cysteine and glutathione.

6. Mixed disulphides of ergothioneine with cysteine and glutathione have been prepared.

The greater part of the work described in this paper was carried out in America but it was completed in England, and one of us (H.H.) wishes to thank Mr R. Boardman for technical assistance in the final stages and Burroughs Wellcome Ltd. for a generous gift of ergothioneine.

\section{REFERENCES}

Ashley, J. N. \& Harington, C. R. (1930). J. chem. Soc. p. 3586.

Balaban, I. M. \& King, H. (1937). J. chem. Soc. p. 1858. Barger, G. \& Ewins, A. J. (1911). J. chem. Soc. 99, 2336. Grote, I. W. (1931). J. biol. Chem. 93, 25.
Heath, H. (1951). Ph.D. Thesis, University of London.

Heath, H., Lawson, A. \& Rimington, C. (1951). J. chem. Soc. p. 2222.

Heath, H. \& Toennies, G. (1955). Proc. 3rd Int. Congr. Biochem., Brussels, p. 4.

Heath, H. \& Wildy, J. (1956). Biochem. J. 64, 612.

Hunter, G. \& Eagles, B. A. (1927). J. biol. Chem. 72, 123.

Kjaer, A. \& Rubinstein, K. (1953). Nature, Lond., 171, 840.

Lyman, C. M. \& Barron, E. S. G. (1937). J. biol. Chem. 121, 275.

Mann, T. \& Leone, E. (1953). Biochem. J. 53, 140.

Mason, S. F. (1954). J. chem. Soc. p. 2071.

Melville, D. B. \& Lubschez, R. (1953). J. biol. Chem. 200, 275.

Pirie, N. W. (1933). Biochem. J. 27, 1181.

Toennies, G. (1937). J. biol. Chem. 120, 297.

Toennies, G. \& Gallan, T. P. (1939). J. biol. Chem. 129, 481.

Toennies, G. \& Kolb, J. J. (1951). Analyt. Chem. 23, 823.

Woodward, G. E. \& Fry, E. G. (1932). J. biol. Chem. 97, 465.

\title{
The Purity of Thyroglobulin Isolated from Normal and Carcinomatous Thyroid Tissue on one Patient by Fractional Salting-out with Ammonium Sulphate
}

\author{
By G. C. EASTY \\ Chester Beatty Research Institute, Royal Cancer Hospital, London, S.W. 3 \\ B. R. SLATER AND P. G. STANLEY* \\ Department of Biochemistry, University of Cambridge
}

(Received 7 June 1957)

Thyroglobulin was prepared (Stanley, 1956) by the method of Derrien, Michel \& Roche (1948) from normal and carcinomatous thyroid tissue of a patient (Mrs Ru.) with a follicular carcinoma of the thyroid gland. The patient had received a tracer dose of radio-iodide 2 days before thyroidectomy. Differences in the distribution of ${ }^{131}$ I between the fractions obtained during the preparation of pure thyroglobulin have been reported and discussed (Stanley, 1956). The homogeneity and question of identity of the thyroglobulins $\left(R u_{N}\right.$ and $\left.R u_{\Delta}\right)$ from normal and carcinomatous thyroid tissue have now been investigated by electrophoresis and by an immunological test.

\section{MATERIAL AND METHODS}

The preparation of $R u_{N}$ and $R u_{A}$ was described previously (Stanley, 1956). Solutions [1\%(w/v);2.5 ml.] of the two proteins in $0.05 \mathrm{M}$-veronal buffer ( $\mathrm{pH} 8.6, I$ 0.05) were subjected to electrophoresis in the $2 \mathrm{ml}$. cell of a Perkin-

* Present address: Department of Chemistry, Indiana University, Bloomington, Indiana, U.S.A.
Elmer apparatus, model 38, after dialysis against the buffer at $0-1^{\circ}$ for at least $16 \mathrm{hr}$. This analysis was repeated with $0.4 \%$ solutions of both proteins.

The solutions of $R u_{N}$ and $R u_{A}$ were recovered from the electrophoresis cells and used for immunological analysis by the method of Ouchterlony (1948). Antibodies against $\mathbf{R u}_{\mathbf{A}}$ were prepared in a rabbit.

\section{RESULTS}

Figs. 1 and 2 represent the electrophoretic schlieren patterns obtained with $1 \%(\mathrm{w} / \mathrm{v})$ solu. tions of $R u_{N}$ and $R u_{\Delta}$ respectively, at the times indicated on the figures. Both proteins contain a single electrophoretic component, but differ significantly in mobility. The mobilities in the descending $\left(\mu_{\mathrm{D}}\right)$ and ascending $\left(\mu_{\mathrm{A}}\right)$ limbs were as follows: $\mathrm{Ru}_{\mathrm{N}}: \mu_{\mathrm{D}} 5 \cdot 38 \times 10^{-5}, \mu_{\mathrm{A}} 5.85 \times 10^{-5} \mathrm{~cm}^{2} \mathrm{v}^{-1}$ sec. $^{-1}$; $\mathrm{Ru}_{\mathrm{A}}: \mu_{\mathrm{D}} 4.97 \times 10^{-5}, \mu_{\mathrm{A}} 5.44 \times 10^{-5} \mathrm{~cm}^{2} \mathrm{v}^{-1}$ sec. $^{-1}$. The difference in mobility was confirmed in a second run with $0.4 \%$ solutions of the proteins, when the following mobilities were determined: $\mathrm{Ru}_{\mathrm{N}}: \mu_{\mathrm{D}} 5.53 \times 10^{-5}, \mu_{\mathrm{A}} 5.71 \times 10^{-5} \mathrm{~cm}^{2} \mathrm{v}^{-1}$ sec. ${ }^{-1}$; $\mathrm{Ru}_{\mathrm{A}}: \mu_{\mathrm{D}} 4.91 \times 10^{-5}, \mu_{\mathrm{A}} 5.09 \times 10^{-5} \mathrm{~cm}^{2} \mathrm{v}^{-1}$ sec. ${ }^{-1}$. 
A contact print of the cell in which a gel-diffusion test of anti-Ru $u_{\mathbf{A}}$ serum was run against $R u_{N}$ and $R u_{A}$ is reproduced in Fig. 3. No antigenic component occurs in $\mathrm{Ru}_{\mathrm{A}}$ which is not also present, in roughly the same proportion, in $R u_{N}$. This test indicates, moreover, the presence of one major and two, possibly three, minor antigenic components in each protein.

\section{DISCUSSION}

Thyroglobulin prepared by the method of Derrien et al. (1948) has been shown by the same workers to be microheterogeneous in spite of the fact that it is isolated by fractional salting-out within narrow limits of ammonium sulphate concentration. This microheterogeneity is indicated by breaks in the solubility curve, which suggest the presence of three components. This microheterogeneity has also been found with thyroglobulin prepared by the same method from human thyroid glands (Roche,

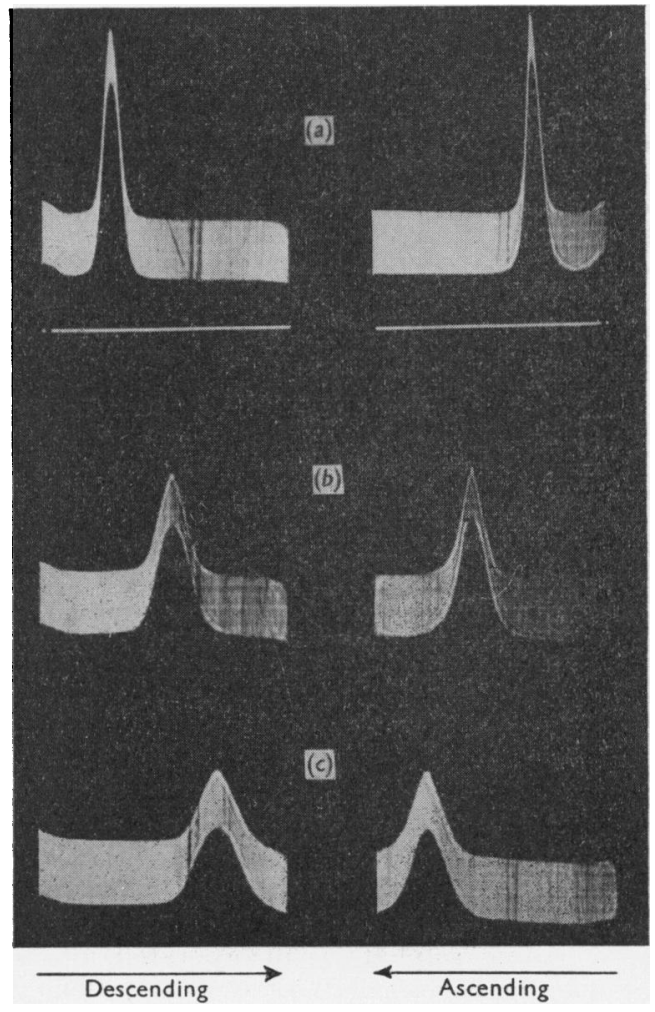

Fig. 1. Electrophoretic schlieren patterns of thyroglobulin $(1 \%, \mathrm{w} / \mathrm{v})$ in $0.05 \mathrm{M}$-veronal buffer $(\mathrm{pH} 8 \cdot 6, I$ 0.05). This sample of thyroglobulin $\left(\mathrm{Ru}_{\mathrm{N}}\right)$ was prepared by the method of Derrien et al. (1948) from the normal thyroid tissue of a patient with a follicular carcinoma of the thyroid gland. Times at which the photographs were taken are: (a) $60 \mathrm{~min}$.; (b) $120 \mathrm{~min}$.; (c) $165 \mathrm{~min}$.
Michel, Deltour \& Michel, 1952). Derrien, Michel, Pedersen \& Roche (1949) demonstrated that thyroglobulin from porcine glands is electrophoretically homogeneous.

In the current investigation thyroglobulin from normal and from carcinomatous thyroid tissue of one patient was shown to be immunologically heterogeneous, each protein containing three antigenic components. Moreover the Ouchterlony geldiffusion test enabled us to conclude that no antigenic components were present in $R u_{A}$ which were not also present in $\mathrm{Ru}_{\mathrm{N}}$.

Electrophoretic analysis suggested that $R u_{N}$ and $\mathrm{Ru}_{\mathrm{A}}$ were homogeneous and had mobilities of the same order as those determined by Derrien et al. (1949) for porcine thyroglobulin in phosphate

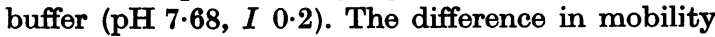
determined for each protein at 1 and $0.4 \%(w / v)$ concentration may be due to a difference in viscosity between the more and less concentrated solutions, but the difference between the mobilities

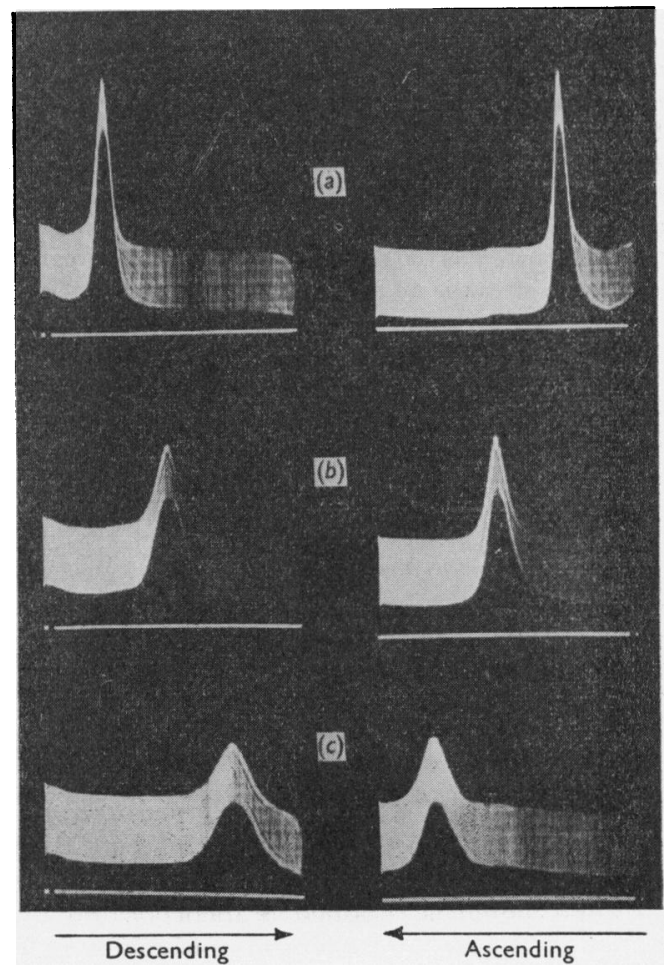

Fig. 2. Electrophoretic schlieren patterns of thyroglobulin

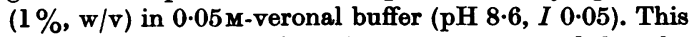
sample of thyroglobulin $\left(\mathrm{Ru}_{\mathbf{A}}\right)$ was prepared by the method of Derrien et al. (1948) from the abnormal thyroid tissue of a patient with a follicular carcinoma of the thyroid gland. Times at which the photographs were taken are: (a) $60 \mathrm{~min}$; (b) $120 \mathrm{~min}$; (c) $180 \mathrm{~min}$. 


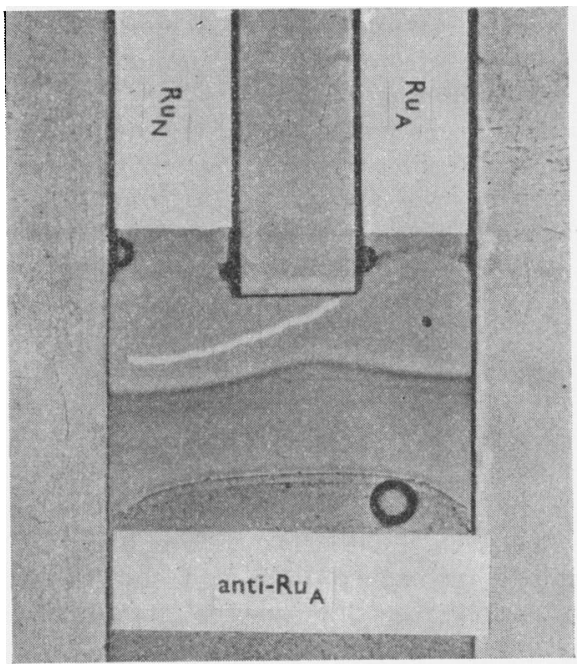

Fig. 3. Gel-diffusion precipitin pattern obtained by the method of Ouchterlony (1948). Solutions (about $1 \%$ in $0.05 \mathrm{M}$-veronal buffer, $\mathrm{pH} \mathrm{8.6)}$ ) of thyroglobulin from normal $\left(\mathrm{Ru}_{\mathrm{N}}, 0.1 \mathrm{ml}.\right)$ and abnormal $\left(\mathrm{Ru}_{\mathrm{A}}, 0.1 \mathrm{ml}\right.$.) thyroid tissue of a patient with a follicular carcinoma of the thyroid gland and an anti-serum prepared against $R u_{A}$ in a rabbit, were placed in the positions marked $R u_{y}, R u_{A}$ and anti- $R u_{A}$ respectively and allowed to diffuse together. At least three precipitin bands formed; the fourth and lowest band, visible also under $R u_{A}$ to the naked eye, was too diffuse to show in the photograph. The white streak is an artifact. of $R u_{N}$ and $R u_{A}$ at the same concentration appears to be due to a structural difference which is not reflected in the antigenic properties of the proteins.

\section{SUMMARY}

1. Thyroglobulins prepared from normal and carcinomatous thyroid tissue of one patient migrated as single components during electrophoresis in $0.05 \mathrm{M}$-veronal buffer ( $\mathrm{pH} 8.6, I 0.05)$ at concentrations of 1 and $0.4 \%(w / v)$. They differed significantly in mobility.

2. Analysis by the gel-diffusion method of Ouchterlony revealed the presence of three, possibly four, antigenic components in each thyroglobulin but no qualitative difference between the two thyroglobulins.

One of us (P.G.S.) is indebted to the University of Melbourne for a Travelling Scholarship, to the British Council for a Travel Grant and to Professor F. G. Young for the provision of laboratory facilities.

\section{REFERENCES}

Derrien, Y., Michel, R., Pedersen, K. O. \& Roche, J. (1949). Biochim. biophys. Acta, 3, 436.

Derrien, Y., Michel, R. \& Roche, J. (1948). Biochim. biophys. Acta, 2, 454

Ouchterlony, Ö. (1948). Ark. Kemi Min. Geol. B, 26, 14.

Roche, J., Michel, O., Deltour, G.-H. \& Michel, R. (1952). Ann. Endocr., Paris, 13, 1.

Stanley, P. G. (1956). Biochem. J. 63, 581.

\title{
Biosynthesis of Intestinal Mucins
}

\section{SURVEY OF INCORPORATION OF [ ${ }^{35}$ S]SULPHATE BY ISOLATED GASTROINTESTINAL TISSUES}

\author{
By C. A. PASTERNAK, P. W. KENT AND R. E. DAVIES* \\ Department of Biochemistry and Medical Research Council Unit for Research in Cell Metabolism, \\ University of Oxford
}

(Received 17 June 1957)

When $\left[{ }^{35} \mathrm{~S}\right]$ sulphate is injected into mammals most of it is eliminated in the urine and faeces (Dziewiatkowski, 1949). The comparatively small amount of isotope which is retained is incorporated by a number of tissues, notably the epithelium of the gastrointestinal tract and cartilaginous tissue (Lewison, Levi, Jones, Jones \& Silberstein, 1951; Dziewiatkowski, 1953; Bélanger, 1954). By the use of radioautographic techniques it has been shown (Bélanger, 1953; Boström, 1953; Davies \&

* Present address: Department of Biochemistry, University of Pennsylvania, Philadelphia 4, U.S.A.
Young, 1954; Jennings \& Florey, 1956) that in the gastrointestinal tract the various mucin-secreting cells are the principal sites of localization and that here inorganic sulphate is incorporated into sulphated amino polysaccharides (Crevier \& Bélanger, 1954; Kent, Whitehouse, Jennings \& Florey, 1956).

In order to study in greater detail the biosynthesis of such polymeric substances, which are major organic components of epithelial mucin, a survey has now been made of the utilization of $\left[{ }^{35} \mathrm{~S}\right]$ sulphate in vitro by surviving slices and segments of various types of gastrointestinal 